\title{
Deploying evidence-based research for socio-economic development policies in Nigeria
}

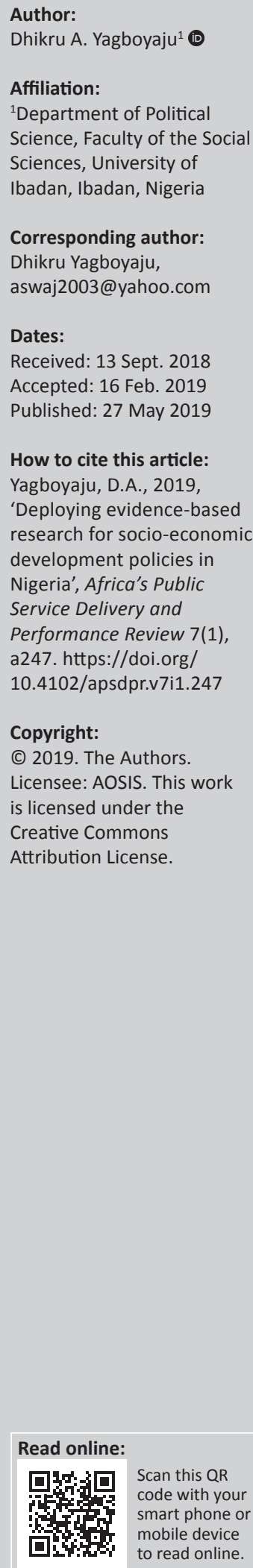

Background: Society's socio-economic development process, which covers ways and means of ensuring the well-being and self-actualisation of the generality of the citizens, requires viable and implementable policies.

Aim: This article analyses the interconnections between evidence-based research, adequate policies and societal advancement in many parts of the developed world, as well as the underperformance in societies with obvious research-policy gaps.

Setting: Using Nigeria as country of study, it focuses attention on how evidence-based research could be deployed more effectively for improved livelihood.

Methods: Data are drawn from historical and contemporary documentary secondary sources. This is complemented by the analyses of selected documented interviews and special reports on aspects of society, economy and politics in the country. The article's framework of analysis draws strength from a combination of role and ecological theories, though it adopts an interpretative research methodology.

Results: It finds out that the ecology of public policies in Nigeria plays a critical role in the gap that exists between policy formulation and implementation.

Conclusion: In its conclusion and recommendations, the article draws examples of best practices from around the world.

Keywords: Socio-economic development; evidence-based research; research-policy gaps; selfactualisation; Nigeria; success-prone policy; sustainable development; societal advancement; public good.

\section{Introduction}

Growth and development require, in their tangible and intangible forms, viable and implementable policies. Policy-makers are the persons bestowed with the power, either by the society as a whole or by a group of people in society, to make such critical decisions (Nzuki, Hassan \& Mbilinyi 2013:1-5). They are, according to Sambo (1999:293), 'the authorities who engage in the daily affairs of a political system', on which they take decisions that are accepted, '... as binding most of the time by most members (of the society) as long as they act within the limits of their roles'. Evidencebased research has become a compelling policy input because of the ever-increasing complex nature of man and his relationship with environment, as well as societal regeneration, which is a product of this relationship. With this critical input, policy design in most countries, where it is popular, has become more relevant and their results delivering desired effects in diverse areas of life. Why are research-based policies often not popular in Nigeria and many parts of the less developed world (see Ajakaiye \& Falokun 2010:871-894)? How and why is this interconnected with Nigeria's failure to realise its full potential despite the country's great human and material endowments? What better effects can education and knowledge production make in the country's development aspiration? What better use could be made of research in the policy processes? These are the questions that this article sets out to address.

The article's primary objective, which is to analyse Nigeria's policy-research nexus and its effects on the country's development process since independence, draws from the aforementioned study questions. Broader objectives of the study include identifying the progress made in evidence-based and scientific researches, articulation of challenges encountered and ascertaining derivable lessons from missed opportunities all of which form the basis of the article's recommendations. The rest of the article is divided into four main sections, namely, definitional or theoretical issues and review of the literature on policy; Nigeria's development plans 
in historical perspectives; lessons in best practices from outside Nigeria and recommendations and conclusion.

\section{Definitional or theoretical issues and review of literature on policy}

There are many prominent definitions of public policy (Anderson 1975; Dye 1976; Eyestone 1971; Goodin, Rein \& Moran 2011). Thus, it may be futile trying to construct an ultimate definition or one that is universally acceptable. However, at a broad level, public policy will, according to Eyestone (1971:18), refer to the 'relationship of a government unit to its environment'. For Dye (1976:1), public policy is typified by 'whatever governments choose to do or not to do'. Public policy can also be associated with purposive behaviour (Anderson 1975; Friedrich 1963). In this regard, public policy is specifically viewed by Anderson (1975:3) as a 'purposive course of action followed by an actor or set of actors in dealing with a problem or matter of concern'. From the many prominent studies such as Easton (1965), Lasswell (1951), Meier (1991), Goodin et al. (2011) and Howlett and Cashore (2014), some distinguishing elements of public policy can be isolated. They are as follows:

- public policy is a purposive or goal-oriented action rather than a random or chance behaviour

- public policy consists of courses or patterns of action by governmental officials

- public policy is what governments do, not what they intend to do or say they are going to do

- public policy involves some form of overt government action on some matter on which governmental involvement is sought

- public policy is based on law and is authoritative. In other words, public policy has an authoritative, potential legally coercive quality that the policies of private organisations do not have (Anderson 1975:3-4).

It is important to note that public policy processes and their operations involve far more than the simple straightforward steps that could be conjured in view of the aforementioned elements. For example, a success-prone policy formulation process is more than likely to consider certain pertinent questions. According to Nzuki et al. (2013:1-4), in a study conducted for Tanzania Knowledge Network (TAKNET), these questions can be clustered into three broad groups. The first set revolves round an understanding of the policy issue at hand. What problems shape the issue? How big is the major problem and is it bigger now than before? Has the nature changed from the previous one? How well can the condition be defined and measured? What are the probable causes, consequences and effects? Defining a policy problem is not an easy task as it involves a multitude of questions and, therefore, requires the ability of policy-makers 'to define clearly and understand the problem or condition they are facing and for which they are expected to develop a response' (Nzuki et al. 2013:1).
The second cluster of questions focuses on what has taken place previously in the form of purposive action or policy on the particular condition or problem. What programmes or projects have previously been initiated to address the problem? How successful were these interventions? Did the previous efforts address the same condition or problem as it currently exists or was it different? If it was different, of what nature was it? If it was the same, why are additional efforts necessary? What are the interest groups involved? What may explain the need for a possible policy change? Finally, the third cluster focuses more on what is known of previous efforts and their impacts that would help one choose among present-day options. According to Nzuki et al. (2013:2), consideration of trade-offs 'is a common option at this level'.

The linkage between the study of politics and policy studies comes to bold relief when theoretical approaches adapted to the analysis of the policy-making process are examined. Theories and theoretical approaches in the study of politics and the study of policy offer separate ways of thinking about these study areas and even suggest some of the general causes and consequences of public policy in particular (see Dye 1997). Decision-making is a component of policy-making, but it is important to note the distinction between theories of policy-making and decision-making theories. Although decision-making involves the choice of an alternative from a series of competing alternatives, policy-making is typically all about a pattern of action, extending over time and involving many decisions, some routine and some not-so-routine. The dominant theories of public policy can broadly be classified into macro- and micro-theories. Systems, group, elite and radical Marxist theories typify macro, while micro-theories are typified by rational-comprehensive theory, incrementalism and mixed scanning (see Sambo 1999).

Public policy theories can, in general, be descriptive and prescriptive, but the aforementioned micro-theories are essentially decision-making theories. Still on theories, it is important to note the relevance of role and ecological theories as they provide the plank upon which the framework of analysis of this study is rested. Role theory is a theoretical framework devoted to the study of behaviour using the notion of role. Each social role is a set of rights, duties, expectations, norms and behaviours that an individual faces or fulfils. Several prominent studies (Banton 1965; Biddle 1979; Mead 1934; Sekhri 2009) have documented the main propositions of role theory about social behaviour. These include division of labour in society, which takes the form of interaction among heterogeneous specialised positions that are called roles, and social roles, including 'appropriate' and 'permitted' forms of behaviour, guided by social norms which are commonly known. Also, roles are occupied by individuals who are called 'actors' and change conditions can render a social role outdated or illegitimate, in which case social pressures are likely to lead to role change. 
The adoption of role theory in political science is widely traced to Ole Holsti's seminal essays on foreign policy and international relations in the 1970s. In subsequent works, such as Holsti (1989:15-43) and Sekhri (2009:423-432), the argument is built around formulations that draw analogies between individuals (in a society) and a state. In other words, the roles ascribed to individuals in the society are applied in the explanation of the behaviour of the state. For this study, focus is on the roles of policy formulators, those who implement, and policy researchers.

Fred W. Riggs (03 July 1917 - 09February 2008) pioneered the adoption of the ecological approach to administrative theory. In support of his propositions, Riggs (1961, 1962 and 1964) borrowed the concepts from subjects such as biology, physics and sociology in explaining the ecological approach to public administration and comparative administrative systems, as well as the influence of the structural-functional approach. The main thesis in this and other prominent works that have adopted the ecological approach or even the theory of prismatic society is that every public administrative system, which includes the policy process, is a product of the peculiar social, cultural, historical, economic, geographical and political milieu within which it operates.

Many studies, especially on democracy's third wave (see Diamond et al. 1997; Huntington 1991), have documented evidences that increased development planning strategies in areas such as trade and financial policy reforms, health and education, power and energy, industrial policies and other development aspirations often constitute the hallmark of democratisation. Of course, this can be attributed to the liberalisation of the political climate, as well as the increase in the legitimate demand for attention by individuals and constituent groups. Simmons (1971), Nzimiro (1971), Sanda (1980) Diejomaoh (1982, 1988), Almeida and Bascolo (2006), United Nations Educational, Scientific and Cultural Organization (UNESCO) (2007), Ajayi and Osafo-Kwaako (2007) and Morandi (2009) have also provided documented evidences. Nigeria, since the 1999 return of civil rule, can also be classified in this group, and this is supported by responses in the series of interviews to mark the 60th anniversary of Nigerian Institute of Social and Economic Research (NISER), in 2010. The document (see NISEREEL 2010) is selected here as part of the special reports for analysis.

Despite this increase, most of the aforementioned works raised issues around and about the not-so-cordial relationship between research outputs and policy formulation, especially in Nigeria and many parts of the less developed world. There have been growing disappointment and dissatisfaction with the content and quality of curriculum, research orientation and relevance, both in universities and designated research institutes. According to Olomola (2005), the research and policy community in Nigeria work at cross-purposes, with every possibility of a worsening condition, except if addressed on time and purposively. Olomola (in Ajakaiye \& Falokun 2010:875) links Nigeria's problem of 'policy inconsistencies, confusion and instability', which are the bane of development in the country, to this 'working at cross-purposes between the research and policy communities'.

The United Nations Educational, Scientific and Cultural Organization, in its concept paper on the realisation of the Millennium Development Goals (MDGs), which transformed in 2015 to Sustainable Development Goals (SDGs), also noted the effects of the lack of a strong commitment to a more dynamic and better integrated research policy nexus on the normative significance such a relationship should generate. This argument, for Edwards (2005), is more about the complexities that fill the policy environments. Again, but specifically, even with policy-relevant research, the results may not have clear policy implications or be conveyed in a way that highlights policy relevance. Apart from this, some policy-relevant researches are 'driven by a combination of academic logic', while others focus on particular challenges because their policy issues are 'crosscutting and involve multiple sectors' such as health, environment, transportation and education (Morandi 2009 in Ajakaiye \& Falokun 2010:875).

Ajakaiye and Roberts (1995:1-22) provide evidence of the potentials in the research-policy relationship in a review of prominent journals in the social sciences. The reviewed journals are classified into four broad groups, namely, philosophy of social science; methodological issues; other basic researches and action or policy researches (see Ajakaiye \& Falokun 2010:878). The list of prominent journals cited in the review consists of Economic and Financial Review, published four times in a year by Central Bank of Nigeria (CBN); African Journal of Economic Policy (AJEP), by Department of Economics, University of Ibadan; Nigerian Journal of Economic and Social Studies (NJESS), by the Nigerian Economic Society (NES); Quarterly Journal of Administration (QJA), by the Institute of Administration, Obafemi Awolowo University; Annals of the Social Science Academy of Nigeria (ASSAN), by the Social Science Academy of Nigeria and Research for Development, by NISER.

There are, of course, many other prominent journals in departments and faculties of diverse backgrounds from across Nigeria's universities, as well as other tertiary institutions, agencies and specialised research institutes. Similarly, there are seminars, workshops, conferences and even training programmes in which papers and research findings are presented for discussion and further analyses (e.g. monthly policy paper presentation at NISER, and periodic departmental seminar presentations at University of Ibadan (UI). The author has been external reviewer at NISER's presentation, while he coordinates the latter for UI's Department of Political Science). These attempts to systematise knowledge production for the improvement of the living conditions of people have also involved civil society organisations (CSOs) and, sometimes, they promote non-technocratic forms of expertise. Health- and educationrelated issues have always benefited from the activities of volunteers and CSOs, while the 20-year period of Nigeria's 
Fourth Republic, since 1999, has also provided evidence of the capacity of CSOs in election and governance-related issues.

Theoretically, roles have been played in Nigeria's public policy processes, but they have not caused the realisation of sustainable development aspirations and goals. For this article, the implied high rate of development policy attrition and failure is essentially a function of the policy environment in the country. Public policy is, of course, largely affected by the nature of society. As postulated by students and scholars of political culture, politics or policy 'is grounded in the nature of the society in which it takes place' (Osaghae 2002:16). The article returns to the adaptability of this framework of analysis in the next section where specific illustrations are drawn for the case of Nigeria.

\section{Nigeria's development plans in historical perspectives}

Nigeria has, since its attainment of flag independence in 1960, made attempts to transform its sociopolitical and economic life with the introduction of development strategies and policies. According to Usman (2010:843), the country adopted as early as 1945 development planning as 'a primary instrument for achieving economic growth and social progress'. Subsequently, the country had four National Development Plans, namely, 1962-1968; 1970-1974; 19751980 and 1981-1985, excluding the regional development programmes of the colonial period of 1945-1960. For Usman (2010:844), each of them consisted of 'deliberate and conscious efforts' to raise the planning horizon and, through institutional transformation, 'broaden consultation and improve plan preparation and implementation'. Specifically, the first plan, upon which subsequent ones rested, was, according to Ajakaiye and Falokun (2010:871), aimed at 'jumpstarting the development of the nation through private sector initiatives'. The plan was structured to make the private sector the engine of economic growth and, therefore, public policies were designed to encourage the development of a broad-based and progressive private sector (see Ajakaiye 1990; Ayo 1988; Ayodele \& Falokun 2003).

The serious economic distortions in the country's Second Republic (1979-1983), which partly accounted for its collapse and which the succeeding military regime could hardly resolve, led to the abandonment of a planned economy and control policies. In 1986, a Structural Adjustment Programme (SAP) was adopted. Essentially, a marketoriented arrangement, it focused on wide-ranging reforms in the economy, especially in the areas of trade, exchange, social and financial systems. However, the broad objectives of SAP and other complementary policies, except for the methods of realisation, were not completely different from those of the regulation era of 1960-1985. For example, the objectives spanned production and consumption diversification, dampening inflation pressures, stimulation of the external sector performance, increasing financial deepening through interest and exchange rate stabilisation, stimulating output and employment growth, infrastructural improvement, and poverty alleviation (see Olukoshi 1993).

Nigeria's sociopolitical and economic decline from the mid1980s to the late 1990s did not go unnoticed. It attracted the attention of writers and scholars as to what the causal factors were and in terms of policy recommendations on the way out. Studies by Lewis (1996) and Joseph (1996) located the decline within the military regimes of the two decades, while Osaghae (2002:311) identified 'the abortion of Babangida's bogus transition programme and the execution of the Ogoni activists', under the Abacha regime, as the catalysts. However, locating the origin of the conversion and exploitation of state offices into instruments of private accumulation both for self and for constituent and kin groups (prebendal politics), a phenomenon, widely believed to be a root cause of Nigeria's sociopolitical and economic problems, obviously requires tracing back to the country's immediate post-colonial era (see Joseph 1996).

In view of this level of decline, it did not come as a surprise that the reintroduction of civil rule in 1999 was accompanied with a lot of expectations for a new beginning in Nigeria. The new administration quickly adopted the National Economic Empowerment and Development Strategy (NEEDS I and II). National Economic Empowerment and Development Strategy, according to the government, was aimed at correcting the social, political and economic decay in the country. It was envisaged to consolidate the achievements of the first 4 years (1999-2003) of the civilian government, by reinforcing the expected solid foundation for sustainable poverty reduction, employment generation, wealth creation and value reorientation (National Policy Commission 2004). With its distinctive feature of a vast array of programmes and areas covered, NEEDS was structured into two parts. National Economic Empowerment and Development Strategy I was planned for 2004-2007, while NEEDS II was expected to run from 2007 to 2011.

This plan changed as soon as the tenure of the initiator ended in 2007. Notwithstanding the commonality of political party affiliation, the administration which commenced in May 2007 jettisoned NEEDS, and introduced the 7-point agenda and Nigeria 20:2020 programmes. The programmes continued, but the then President Umar Yar'Adua died in 2010, before the expiration of his first term, leaving his deputy to take over as president. Again, party commonality and joint presidency notwithstanding, President Goodluck Jonathan, who was also re-elected in 2011, discontinued the programmes he inherited and introduced the Transformation Agenda, which operated till 2015 when another administration came on board. For more than 3 years after its inauguration in May 2015, the current administration has operated the Economic Recovery and Growth Plan (ERGP). A distinctive feature in all of this is the usual discontinuity of policies and plans by successive administrations. 
The relatively high number of policy research and specialised training institutions established across Nigeria - more than 80 as of 2018 (see Ajakaiye \& Falokun 2010:888-892; Department for International Development 2007; National Planning Commission 2018) - gives an impression that the importance of the research-policy nexus is recognised. In addition, especially under successive military regimes, there were executive directives that led to the setting up of ad hoc committees, special panels and commissions on various aspects of important sociopolitical and economic issues. Yet, Nigeria's level of development, using indicators by United Nations Human Development Index (HDI), Mo Ibrahim Foundation Index of Africa Governance (IIAG) and World Bank annual reports, among others, is at variance with expectations.

A compendium of interviews granted, in 2010, by past Directors General of NISER, in commemoration of the institute's 60th anniversary celebrations (see NISEREEL 2010) provides some tips on issues often raised in connection to policy attrition and failure in Nigeria. Those interviewed are Profs H.M.A Onitiri (the pioneer Director), V.P. Diejomaoh, A.O. Phillips, D.O. Ajakaiye and S.O. Akande (the then DG). The commonest point of convergence in their responses is that policies in the country are hardly research based, while many research outputs are merely 'hit and run' as they lack strong evidence of rigour. Such outcomes would complicate the confusion and uncertainties that often typify policy conception in the country.

Similarly, several leading studies, including Akinwowo (1971), Ake (1979), Ajakaiye and Roberts (1995, 1997) and Ajakaiye and Falokun (2010), posit that social scientists, in particular, have been confronted by the problem of relevance of their research outputs to public policy. For many of such researchers who seem unconcerned with the policy implications of their work, focus is more on their 'own interests, and basic understanding of issues'. For them, and in the words of Nzuki et al. (2013:2), research has become 'an industry in itself', working 'independently in some cases'.

The point made earlier can, in a way, imply lack of confidence in local research outputs or, using a buzzword, lack of political will on the part of policy-makers and authorities to develop a policy agenda which recognises local contents for local problems. Hirschman (in Sambo 1999:305) puts it aptly as the 'introduction of policy solutions from elsewhere', while Ake (1981:32-33) placed this problem in the context of post-colonial societies that are still largely economically dependent on their colonial masters, the fact of political independence notwithstanding.

In the same token, a report by the Department for International Development (DFID) in 2007 emphasised the lack of political will and on the other hand, limited political value of research in the policy process. From a broader perspective, this problem, according to Myrdal (1990), may not be totally unconnected to the problems of 'soft states'. Such states are known for features of personal rule, including acute social indiscipline, corruption, arbitrary enforcement of the law and general abuse of power and privileges. Thus, it is no surprise that policy inputs are also selected arbitrarily. Also, this raises the issue of research institutes that are seen as mouthpieces of the government of the day. In other words, they are not supposed to be critical of government policies. This limits the capacities and resources of these institutions to conduct proper researches.

The point being made here distinctively featured in the 2010 compendium of interviews by past DGs of NISER. It also resonated in this author's personal interaction with a research professor in NISER, on 05 January 2018. This challenge is, without prejudice to regime types, more prevalent under military dispensations for obvious reasons that are connected to personal rule. For example, it was common under successive military regimes in the country to concentrate on the research units of Ministries, Departments and Agencies (MDAs). Thus, many leading research institutes were abandoned and denied required funding. Meanwhile, as reported in studies by Adamolekun (1983), Ayo (1988) and Usman (2010), many of the researches by the MDAs suffered a lack of technical skills because they were mostly conducted by generalist administrators. Examples of such research outputs include SAP that the Babangida regime promoted, the Vision 2010 by the Abacha military regime of 1993-1998 and several feasibility studies on the downstream oil and gas industries, refineries, cement, fertiliser, iron, steel and paper production.

The factors of education, enlightenment, exposure and technology cannot also be underestimated in the mutually reinforcing relationship of policy inconsistency and sociopolitical and economic underdevelopment in Nigeria. The country has a poor culture in this regard as many communities hardly understand why the most informed should represent them in the critical areas of policy formulation. Twenty years after the commencement of its Fourth Republic, which coincide with two decades into the 21st century, Nigeria's encounter with the development conundrum can hardly be separated from this lack of knowledge-driven political representation, policy formulation and governance, in general.

Funding is another critical factor that featured in the 2010 NISER 60th anniversary interview with past DGs and the institution's DG at that time. It also resonated in this author's conversation with a prominent research professor in the institute on 05 January 2018. Inadequate funding for any human development programme is inimical, but portends greater danger when it involves education. This largely accounts for the general demotivation and demoralisation for researchers in many parts of Nigeria. For example, the whole of the country's education sector has never had beyond $10 \%$ annual budgetary allocation in the 20-year-old Fourth Republic (Yagboyaju 2016:99-131). This is a far cry from the $26 \%$ benchmark recommended 
by UNESCO. The practice in Nigeria is, according to Olukotun (2014:64), also at variance with the prevailing condition among its peers 'in the world's emerging centres of industrial and economic prominence such as Malaysia, Singapore and South Korea', and even in African countries such as Kenya, South Africa and Rwanda where for almost a decade since 2010 'about a quarter of annual budgets is consistently allocated to education'.

Even for NISER that is classified as Nigeria's think tank in terms of policy research, as well as other prominent research institutes that are under direct supervision of the National Planning Commission, inadequate funding is also a problem. In some of these cases, funding is accessed from non-governmental organisations, especially from outside the country, but this is incommensurable with the amount of research the country requires. It is even more worrisome, according to Kew (2004:101), because most of the external funding comes from the same sources such as 'Ford Foundation, British Council, USIS and Swedish NGO Foundation'. This could promote a kind of unhealthy rivalry rather than competition among the major actors as they seek access to such research funds. Nonetheless, aspects in NISER's compendium (see NISEREEL 2010) emphasised the criticality of the cooperation with foreign agencies, such as the United States Agency for International Development (USAID), United Nations (UN) and United Nations Development Programme (UNDP), because these agencies require reputable researchers who can respond to their research needs in connection with their activities in Nigeria.

In all, 58 years after Nigeria's flag independence in 1960, a critical issue that summarises the challenge of policy attrition and failure in the country, and which calls to question the relationship between research and policy processes in the country, has been raised by Akande and Roberts (2010:1-29). Nigeria, once a major exporter of agricultural commodities and great promise in other sectors, is today a net importer of practically everything.

\section{Lessons in best practices from outside Nigeria}

Singapore, Malaysia, China and Kenya are selected for lessons in best practices for various reasons. Firstly, Singapore and Malaysia were for long classified as peers of Nigeria after the flag independence of these countries around and about the same time in the 1960s. Secondly, and in the case of China, population that is sometimes pushed as a limiting factor for Nigeria's development aspirations has obviously not hindered development in the world's most populated country. Thirdly, Kenya is not only an African country like Nigeria, but attained flag independence at about the same time as Nigeria. Both countries also share a lot of similarities in terms of the coming together of diverse ethnic nationalities, abuse of official positions and such corruptive tendencies, whereas Kenya is not as endowed as Nigeria in terms of natural resources. Fourthly, the selected countries have distinguished themselves in their various regions for consistency.

In Singapore, development planning efforts backed by evidence-based research are widely acknowledged as quite impactful when compared to those of other ASEAN countries. According to Usman (2010:843-870), although the country has relied more on the market mechanism, Singapore has formulated several development plans from 'the first plan of 1960-1965, to the seventh development plan, and the 1991-2000 Strategic Economic Plan'. In addition to the broad overview in the Seventh Plan, there are a number of complementary and supplementary plans, including the national technology plans, the manpower plan, social plans in the areas of health, education and housing. By the mid1990s, Singapore became one of the world's most prosperous economies, with the highest per capita gross domestic product (GDP) in Asia outside Japan. The country has remained consistent and, according to the studies by Obadan (2003) and Usman (2010), it also has long-term economic and social development plans providing mechanisms for opportunities to clear bottlenecks or to troubleshoot potential problems.

Malaysia is a multiracial society probably more variegated than Nigeria. It inherited at independence a highly skewed income distribution, with high and widely spread poverty. This affected all ethnic groups, but, according to Dholakia and Dholakia (1994:57), the incidence of poverty was 'disproportionately high among the Bhumiputras', and other rural areas. Malaysia's New Economic Policy (NEP) was launched in 1971, and it showed evidences of rigorous research. It accorded the highest priority to poverty eradication and, in particular, reduction of racial imbalance in income, and enhancement of employment and ownership of assets. As planned, economic growth and the growing prosperity of the 1990s has not only been sustained, but has also helped in minimising political discontent across Malaysia. Evidences supporting Malaysia's consistent economic growth are available in a report by World Bank Malaysia Economic Monitor launched in July 2018 and in which a 5.4\% growth forecast was made for Malaysia in 2018 (The World Bank 2018).

China is another example of evidence-based research outcomes. With a population of 1.4 billion as of 2016, China is the world's most populous country, and the third largest globally in terms of land area. In the 1970s, China was, according to Usman (2010:859), 'a poor, centrally-planned, overpopulated country, hostile to outsiders and opposed to radical reform'. Things changed and, as of 1995 after overcoming the effects of the self-inflicted economic disasters of the Great Leap Forward of 1958-1960 and the Cultural Revolution of 1966-1979, China, according to Cleaver (2007:47), had a GDP that was 'almost five times greater than Russia's and its income per capita reached $60 \%{ }^{\prime}$. It is important to note the phenomenal rise because two decades before 1995, China's economy was 
'half the size of Russia's and its income per capita represented only 15\%' (Usman 2010:859).

China's GDP was $\$ 12.24$ trillion as of 2017 , with an annual growth rate forecast of $6.9 \%$ in the same year (The World Bank 2018). It is important to note that China's re-emergence as a global superpower, especially since the turn of the 21st century, cannot be separated from the country's educational and research policies that have also witnessed fundamental transformation. These include the Rejuvenation Action Plan, 2003-2007, curricular reform and system innovations, which Li (2017:133-141) has put in clear perspectives. These reforms are usually introduced in a pilot or experimental fashion, and usually in restricted localities where results can be observed and lessons learned. Also, ends are usually not confused with means in the Chinese model, and violations are strongly and openly reprimanded and punished if necessary. The UN's 2016 HDI and World Development Indicator of 2016 reported an unemployment rate of less than $4 \%$ for China despite the country's huge population.

Kenya is, as noted, part of the African continent like Nigeria and both have had a series of development plans just as they both adopted SAP at some points in time. The major points being made here centre on Kenya's integrated approach to planning, with evidences of research backings, and the country's policy consistency, in particular. For example, Kenya's sixth development plan was formulated on the framework provided by the perspective plan for 1984-2000. This is outlined in Sessional Paper No. 1 of 1986 and the country's Economic Management for Renewed Growth. The basic development philosophy of this plan was consistent with the one contained in Sessional Paper No. 10 of 1965 on African socialism and its application to planning in Kenya. According to Dholakia and Dholakia (1994:58-59), these objectives were social justice; human dignity; freedom from want, disease and exploitation; equal opportunities for all; and high and growing per capita. Kenya, like Nigeria, performs poorly in international rankings such as the UN HDI. For example, in the 2016 report, Kenya and Nigeria were placed in 145 and 152, respectively, out of the 188 countries in the survey. However, Kenya without as much resource endowment as Nigeria, consistently improves its ranking.

It is necessary to return to the research questions set at the beginning of the article before concluding. The first and second questions are on the failure to embrace researchbased policies, despite the existence of research centres in Nigeria. These questions are necessary because of the developmental problem of frequent policy attrition and failure to achieve objectives. The third and fourth questions focus on the roles of education and knowledge production on the realisation of the developmental goals and reinventing of policy processes in Nigeria. This is important in view of the broad and deep relationship between education and transformation. The article's recommendations are based on the questions raised earlier.

\section{Conclusion}

Deploying evidence-based research for socio-economic development policies in Nigeria is a compelling need. Evidences from around the developed and even emerging economies support this. For example, research is an aspect of the general body of knowledge acquired through education. Education and social transformation are interconnected as one constitutes the extent and level of realisation of the other. However, while the role of policy formulation and implementation is variously performed in Nigeria, several factors in the ecology of the country's public administrative system hinder rigorous research inputs in the policy processes.

\section{Recommendations}

In view of the dangers that a long-term lack of evidencebased research policy processes portend for Nigeria's socioeconomic development, there is an urgent need to purposively pursue the following:

- Greater emphasis on clear policy research implication: Government research institutions, as well as tertiary training and learning centres, especially those classified as think tanks in Nigeria, must emphasise research results with clear policy implications for government actions or future actions. This will improve government capacity to recognise and absorb research outcomes.

- Adequate funding of researches and research institutions: Inadequate budgetary allocations and, worse still, budgetary releases without cash backing have for long crippled research efforts, and this must be effectively addressed for improved results and impact. In addition, donor-driven researches must be managed in accordance with best practices.

- Timeliness and priority of demand-driven research: If research findings are to influence policy, then they must do so at the appropriate time and, importantly, they must be driven by demand. The relevance of demand-driven research is in its capacity to remove the problems of lack of awareness among politicians and bureaucrats concerning the existence of policy-relevant research. In essence, rather than creating parallel research groups, universities, polytechnics and Nigeria's think tanks should be challenged from time to time and required to make the necessary input regarding policy questions policy questions that confront the government. By doing so, quality time is being devoted to thinking ahead. In addition, research centres must collaborate with others in monitoring and evaluating policies for realising economic inclusion, social development, political participation, democracy and trust building for effective governance and decisionmaking. Human Sciences Research Council (HSRC) of South Africa is a relevant example that can be emulated.

- Addressing the disconnection between policy team and society: It must be ensured that both researchers and policymakers are vitally connected to the society for which the research findings and subsequent policies are intended. 
Indeed, this is the basis for evidence-based research because a research outcome is as good as its applicability to the society. Prominent CSOs have a role to play in this culturally related goal.

- Improving techniques for communication and dissemination of research result: The adequacy of research infrastructure, including funding, will combine to improve the techniques for communicating and disseminating research results and, ultimately, improving the quality of policies.

- Above all, Nigeria is unlikely to have effective policies as a 'soft state'. Therefore, the autonomy and functionality of the state must be restored by making its institutions independent and less personalised.

\section{Acknowledgements}

The author is appreciative of the enabling research environment provided by the University of Ibadan.

\section{Competing interests}

The author declares that he has no financial or personal relationships that may have inappropriately influenced him in writing this article.

\section{References}

Adamolekun, L., 1983, Public administration: A Nigerian and comparative perspective, Longman, Lagos.

Ajakaiye, D.O., 1990, Public enterprise policies in Nigeria: A macro-economic analysis, NISER, Ibadan.

Ajakaiye, D.O. \& Roberts, F.O.N., 1995, 'Social research in Nigeria: Which way forward?', Annals of the Social Science Council of Nigeria 7, 1-22.

Ajakaiye, D.O. \& Roberts, F.O.N., 1997, 'Social research in Nigeria: The problem of policy relevance', Journal of Humanities and Social Science 8(2), 249-268.

Ajakaiye, D.O. \& Falokun, G.O., 2010, 'Policy research Nexus: Its impact on socioeconomic development', in S.O. Akande \& A.J. Kumuyi (eds.), Nigeria at 50-accomplishments, challenges and prospects, NISER, Ibadan.

Ajayi, K. \& Osafo-Kwaako, P., 2007, Research and trade policy formulation: The case of Nigeria's adoption of the ECOWAS Common External Tariff, Latin American Trade Network, Hamburg.

Akande, S.O. \& Roberts, F.O.N., 2010, 'Nigeria: Profile of a giant in the sun', in S.O. Akande \& A.J. Kumuyi (eds.), Nigeria at 50 - Accomplishments, challenges and prospects, NISER, Ibadan.

Ake, C., 1979, 'Social science, dependence and underdevelopment', presented at the National Workshop on the Impact of the Social Sciences on Policy in Nigeria, NISER, Ibadan, June 04, 1979, pp 1-20.

Ake, C., 1981, 'The political context of indigenization', in A. Adedeji (ed.) Indigenization of African economies, pp. 50-65, Hutchinson \& Co. Publishers Ltd., London.

Akinwowo, A.A., 1971, 'Linkages between social science research and decision makers in Nigeria', The Quarterly Journal of Administration 2, 217-227.

Almeida, C. \& Bascolo, E., 2006, 'Use of research results in policy decision-making. Formulation and implementation: A review of the literature, Debate S7', Cadernos de Saúde Pública 22, 57-533.

Anderson, J.E., 1975, Public policy making, Praeger, New York.

Ayo, E.J., 1988, Development planning in Nigeria, Ibadan University Press, Ibadan.

Ayodele, S.A. \& Falokun, G.O., 2003, The Nigerian economy: Structure and pattern of development, JODAD Publishers, Ibadan.

Banton, M., 1965, Roles: An introduction to the study of social relations, Basic Books, New York.

Biddle, B.J., 1979, Role theory: Expectations, identities and behaviours, Academic Press, New York.

Cleaver, T., 2007, Understanding the world economy, Routledge, Abingdon, UK.

Department for International Development (DFID), 2007, Research strategy (20082013) consultation, Africa Country Report for Nigeria, Department for Internationa Development, Abuja.

Dholakia, B.H. \& Dholakia, R.H., 1994, Economic and management planning: Case studies of some commonwealth countries, The Commonwealth Secretariat, London.
Diamond, L., Plattner, M.F., Chu, Y. \& Tien, H. (eds.), 1997, Consolidating the third wave democracies, Stanford University Press, Stanford, CA.

Diejomaoh, V.P., 1982, 'Social science research priorities for national development', Research for Development 2(1), 7-19.

Diejomaoh, V.P., 1988, 'Building and developing the Nigerian nation: The role of positive social science', Annals of the Social Science Council of Nigeria 1, 5-13.

Dye, T., 1976, Policy analysis: What governments do, why do they do it and what difference it makes, University of Alabama Press, Birmingham, AL.

Dye, T., 1997, Understanding public policy, Prentice-Hall, Upper Saddle River, NJ.

Easton, D., 1965, A framework for political analysis, Prentice-Hall, Upper Saddle River, NJ.

Edwards, M., 2005, Social science research and public policy: Narrowing the divide, National Institute of Governance, University of Canberra, Canberra.

Eyestone, R., 1971, The threads of public policy: A study in policy leadership, BobbsMerrill, Indianapolis, IN.

Friedrich, C.J., 1963, Man and his environment, McGraw Hill, New York.

Goodin, R.E., Rein, M. \& Moran, M. (eds.), 2011, Overview of public policy: The public and its policies, Oxford University Press, Oxford.

Hirschman, A.O., 1963, Journeys toward progress: Studies of economic making policy in Latin America, Twentieth Century Fund, New York.

Holsti, O.R., 1989, 'Models of international relations and foreign policy', Diplomatic History 13(1), 15-43. https://doi.org/10.1111/j.1467-7709.1989.tb00042.x

Howlett, M. \& Cashore, B., 2014, 'Conceptualizing public policy', in I. Engeli \& C.R. Allison (eds.), Comparative policy studies, pp.200-201. Palgrave Macmillan, London.

Huntington, S.P., 1991, 'Democracy's third wave', Journal of Democracy 2(2), 12-34. https://doi.org/10.1353/jod.1991.0016

Joseph, R., 1996, 'Nigeria: inside the dismal tunnel', Current History 95(601).

Kew, F., 2004, 'The third generation of civil society: The rise of non-governmental organizations in the 1990s', in A. Agbaje, L. Diamond \& E. Onwudiwe (eds.), Nigeria's struggle for democracy and good governance, pp. 196-200, Ibadan University Press, Ibadan.

Lasswell, H., 1951, 'The policy orientation', in D. Lerner \& H. Lasswell (eds.), The policy sciences, pp.1-5, Stanford University Press, Stanford, CA.

Lewis, P.M., 1996, 'From prebendalism to predation: The political economy of decline in Nigeria', Journal of Modern African Studies 34(1), 79-103. https://doi.org/ $10.1017 /$ S0022278X0005521X

Li, J., 2017, 'New trends of educational policies in China: Transcending localization and globalization', Chinese Education \& Society 50(3), 133-141. https://doi.org/ 10.1080/10611932.2017.1330992

Mead, G.H., 1934, Mind, self and society, University of Chicago Press, Chicago, IL.

Meier, G.M., 1991, Politics and policymaking in developing countries: Perspectives on the new political economy, International Center for Economic Growth Press, San Francisco, CA.

Morandi, L., 2009, Essential Nexus: How to use research to inform and evaluate public policy, National Conference of State Legislatures, Denver, CO.

Myrdal, G., 1990, The challenge of world poverty, Vintage, New York.

National Planning Commission (NPC), 2018, List of research institutes in Nigeria viewed n.d., from https://sites.google.com/site/gidiviews/new-page

National Policy Commission (NPC), 2004, National Economic Empowerment and Development Strategies (NEEDS), NPC, Abuja.

Nzimiro, I., 1977, The crisis in the social sciences: The Nigerian situation, Third World Forum Occasional Paper, No. 2, Third World Forum Coordinating Secretariat, Mexico.

Nzuki, M., Hassan, A. \& Mbilinyi, A., 2013, Bridging the research policy gap: The impact of research on policy process and practice, Tanzania Knowledge Network (TAKNET) Policy Brief Series, No. 019-2013, pp. 1-4, Tanzania Knowledge Network (TAKNET), Dar es Salaam.

Obadan, M.I., 2003, National development planning and budgeting in Nigeria: Some pertinent issues, Broadway Press Ltd., Lagos.

Olomola, A.S., 2005, An analysis of the research-Policy Nexus in Nigeria, paper for the International Conference on African Economic Research Institutions and Policy Development: Opportunities and Challenges, Dakar, January 28-29.

Olukoshi, A.O. (ed.), 1993, The politics of structural adjustment in Nigeria, James Currey, London.

Olukotun, A., 2014, 'For a change, a burst of excellence', The Punch (Lagos, Nigeria), June 20, p. 64

Osaghae, E.E., 2002, Nigeria since Independence: Crippled giant, John Archers, Ibadan.

Riggs, F.W., 1961, The ecology of public administration, Asia Publishing House, India.

Riggs, F.W., 1962, 'Trends in the comparative study of public administration', International Review of Administrative Sciences 28(1), 9-15. https://doi.org/ $10.1177 / 002085236202800102$

Riggs, F.W., 1964, Administration in developing countries: The theory of prismatic society, P. Houghton Mifflin \& Co., Boston, MA

Sambo, A., 1999, 'What is public policy?', in R. Anifowose \& F. Enemuo (eds.), Elements of politics, pp.305-309, Sam Iroanusi Publishers, Lagos. 
Sanda, A.O., 1980, 'Social science and policy: The Nigerian experience', Africa Development 4, 49-59.

Sekhri, S., 2009, 'The role approach as a theoretical framework for the analysis of foreign policy in third world countries', African Journal of Political Science and International Relations 3(10), 423-432.

Simmons, R.J., 1971, 'Making social science relevant to development change problems: The communication of research findings', Quarterly Journal of Administration 2, 207-216.

The United Nations Educational, Scientific and Cultural Organization (UNESCO), 2007 Social development: From research to policy action, Draft Concept Paper, Revision 2, United Nations Educational, Scientific and Cultural Organization, Paris.
World Bank, 2018, World development indicators, World Bank, Washington, DC.

United Nations Development Programme (UNDP), 2016, Human development report, viewed 24 December 2017, from http://hdr.undp.org/sites/default/files/2016 human_development_report.pdf

Usman, S., 2010, 'Planning and national development', in S.O. Akande \& A.J. Kumuyi (eds.), Nigeria at 50-Accomplishments, challenges and prospects, pp. 710-724, NISER Research Seminar Series (NISER), Ibadan.

Yagboyaju, D.A 2016, 'Human capital and social sector development', in D.A. Yagboyaju (ed.), Reflections on politics, governance and the economy in contemporary Nigeria, pp. 74-85, Ibadan University Press, Ibadan. 